\title{
СУЧАСНІ НАПРЯМИ СТРАТЕГІЧНОГО РОЗВИТКУ НАЦІОНАЛЬНОЇ ВИДАВНИЧО-ПОЛІГРАФІЧНОЇ ГАЛУЗІ
}

\author{
MODERN DIRECTIONS OF STRATEGIC DEVELOPMENT \\ OF THE NATIONAL PUBLISHING AND POLYGRAPHIC INDUSTRY
}

\author{
Михайловська О. В. \\ кандидат економічних наук, доцент, \\ доцент кафедри публічного управління \\ та менеджменту організацій, НУ «Чернігівська політехніка», Чернігів \\ ORCID: 0000-0002-7682-2292 \\ Olena Mykhailovska \\ Candidate of Economic Sciences, Associate Professor, \\ Associate Professor at the Department of Public Administration \\ and Organizations' Management, \\ Chernihiv Polytechnic National University, Chernihiv
}

У статті досліджено стан розвитку видавничо-поліграфрічної галузі Україні, розкрито проблемні питання ї фрункціонування, окреслено пріоритетні напрями подальшого руху. Встановлено, що значущість галузі в житті суспільства визначається: присутністю поліграфрічної продукції в усіх сфрерах життєдіяльності; необхідністю людського спілкування та обміну інформацією. Окреслено негативні фрактори у фуункціонуванні видавничо-поліграфічної галузі та наголошено, що першочерговості набуває проблема пошуку шляхів використання стратегічного потенціалу галузі в умовах обмежених ресурсів. Схарактеризовано деякі показники діяльності галузі. Констатовано наявність проблем у видавничій справі на національному рівні та встановлено, що поза увагою залишаються стратегічні проблеми поліграфрічної сорери. Визначені засоби державного впливу на стратегічний розвиток видавничо-поліграфрічної галузі. Представлено етапи формування подальшого стратегічного розвитку видавничо-поліграфрічної галузі України. Ключові слова: стратегія, розвиток, стратегічний розвиток, видавничо-поліграфрічна галузь, потенціал.

В статье исследовано состояние развития издательско-полиграфической отрасли Украины, раскрыто проблемные вопросы ее фрункционирования, определены приоритетные направления дальнейшего развития. Установлено, что значимость отрасли в жизни общества определяется: присутствием полиграфической продукции во всех сфрерах жизнедеятельности; необходимостью человеческого общения и обмена информацией. Определены негативные фракторы в процессе фрункционировании издательско-полиграфрической отрасли и отмечено, что первоочередность приобретает проблема поиска путей использования стратегического потенциала отрасли в условиях ограниченных ресурсов. Охарактеризованы некоторые показатели деятельности отрасли. Констатировано наличие проблем в издательском деле на национальном уровне и установлено, что без внимания остаются стратегические проблемы полиграфической сферы. Определены средства государственного влияния на стратегическое развитие издательско-полиграфической отрасли. Представлены этапы формирования дальнейшего стратегического развития издательско-полиграфической отрасли Украины. Ключевые слова: стратегия, развитие, стратегическое развитие, издательско-полиграфрическая отрасль, потенциал.

The article examines the state of development of the publishing and printing industry in Ukraine, reveals the problematic issues of its functioning, outlines the priority areas for further movement. It is established that modern integration processes actualize the search for complex directions of strategic development of the national publishing and printing industry. It was found that the importance of the industry in society is determined by: the presence of printed products in all spheres of life; the need for human communication and information exchange. Negative factors in the functioning of the publishing and printing industry are highlighted: dependence on imports of materials and equipment; illegal import of printed products; depreciation of funds; corruption obstacles, etc. It is emphasized that the problem of finding ways to use the strategic potential of the industry in conditions of limited resources is becoming a priority. The objectivity of the issue of obtaining statistical data on the activities of the industry is indicated. Some indicators of the industry's activity are considered (share of printing activity and reproduction of recorded information in domestic industry; number of business entities by type of economic activity "printing activity, reproduction of recorded information" in Ukraine 2010-2019; structure of industry products, etc.). It is emphasized that the speed of information transfer plays an important role in the publishing business, and the use of non-publishing products remains at a high level. The strategic prospects of establishing the Ukrainian Book Institute are revealed. The existence of problems in the publishing business at the national level was stated and it was established that the strategic problems of the printing sphere were ignored. Means of state influence on the strategic development of the publishing and printing industry are identified. The experience of development of associated forms of management in the industry is detailed. The stages of formation of further strategic development of publishing and printing industry of Ukraine are presented. Key words: strategy, development, strategic development, publishing and printing industry, potential. 
Постановка проблеми. Інтеграція української економіки до світової в цілому, а також до європейського економічного простору зокрема, актуалізує пошук та формалізацію комплексних шляхів стратегічного розвитку національної видавничополіграфічної галузі. В умовах стрімкого поширення трансформаційних змін в Україні питання розбудови дієвої стратегії розвитку різних галузей економіки потребують першочергового вирішення. Зазначене акцентує увагу саме на видавничополіграфрічній галузі, оскільки ії значимість в житті суспільства визначається не лише присутністю поліграфрічної продукції в усіх сфрерах життєдіяльності (етикетка, зошити, книжки тощо), а й залишається одним із засобів людського спілкування та обміну інформацією, формою людської культури. Отже, її справедливо розглядають як елемент не лише соціально-економічних, культурних, а й політичних та військових процесів. Водночас через певні негативні фрактори: залежність від імпорту матеріалів та обладнання; нелегальний імпорт друкованої продукції; зношеність фондів; корупційні перешкоди тощо, питання пошуку ефективних напрямів стратегічного розвитку видавничополіграфічної галузі досі потребує особливої уваги.

Аналіз останніх досліджень і публікацій. У сучасній науковій літературі продовжується дискусія з приводу формування найефективніших шляхів розбудови видавничо-поліграфрічної сфери в умовах змін. Чисельні дослідження присвячені пошуку чинників, вплив яких гальмує та ускладнює розвиток галузі. Серед найдетальніших з них слід виділити роботи Я. Котляревського, О. Мельникова, Є. Палиги, В. Сеньківського, Л. Швайки, А. Штангрета, та інших. Однак, більшість розробок стосуються лише окремих сфер видавничополіграфрічної діяльності та не деталізують кроки стратегічного розвитку галузі.

Виділення невирішених раніше частин загальної проблеми, котрим присвячується означена стаття. Сучасні процеси соціально-економічних перетворень в Україні посилюють невизначеність зовнішнього середовища, в якому функціонує видавничо-поліграфічна сфера та ускладнюють довгострокове планування ії подальшого розвитку, що вимагає постійного оновлення та систематизації основних пропозицій щодо стратегічного розвитку галузі з урахуванням останніх тенденцій.

Формулювання цілей статті (постановка завдання). Метою даної статті $€$ дослідження сучасного стану національної видавничополіграфрічної галузі та фрормування комплексних пропозицій щодо ії̈ подальшого стратегічного розвитку.

Виклад основного матеріалу дослідження. Ключові тенденції розвитку економіки в сучасній Україні вимагають підвищення рівня функціону- вання національної видавничо-поліграфічної галузі, що включає зміцненням її конкурентоспроможності не лише на внутрішньому ринку, а й на зовнішньому. Враховуючи зазначене першочерговості набуває проблема пошуку шляхів використання стратегічного потенціалу галузі в умовах обмежених ресурсів.

Варто зазначити, що залишається проблематичним питання отримання статистичних даних щодо діяльності саме видавничо-поліграфрічної галузі, оскільки за даними Державною службою статистики України [1] більшість даних щодо поліграфічної діяльності наводяться разом з тиражуванням записаної інфрормації. Також виготовлення виробів з паперу та картону може включати поліграфрічну діяльність, що ускладнює отримання достовірних даних. Не враховуючи наведене, у січні-березні 2019 року частка поліграфічної діяльності та тиражування записаної інформації у вітчизняній промисловості сягала лише 0,4\% до загального обсягу реалізованої промислової продукції, та 4,9\% з нього склав обсяг реалізованої продукції промисловості за межі країни. Однак, реальне значення галузі важко переоцінити. На рис. 1 представлено дані щодо кількості суб'єктів господарювання за видом економічної діяльності «поліграфрічна діяльність, тиражування записаної інфрормації». Отже, з 2015 року відбувається незначне падіння загальної кількості підприємств видавничо-поліграфічної галузі. Водночас зазначимо, що обсяг нових замовлень продовжує зростати, але їх іноземна частка знижується. У структурі продукції найбільшу частку займає виробництво газет, журналів та періодичних видань, які виходять менше чотирьох разів на тиждень. Друге місце займають книги, брошури, листівки та подібна продукція (таблиця 1).

За офріційними даними Книжкової палати України [2] серед усіх видань: найбільше навчальної літератури; художня література за кількістю назв (друге місце); за накладами на другому місці - дитяча книжка. Зауважимо, що рекордною останніми роками є кількість видань за назвами українською мовою. Водночас показники за кількістю накладів у 2021 році залишаються в цілому нижчими за кризовий період (2009 рік) й значно меншими за рекордний 2013-й. Додаткову інформацію щодо сучасного стану книжкових видань в Україні можна знайти на офріційному сайті Книжкової палати України: http://www.ukrbook.net/statistika_. $\mathrm{html}$. В цілому об'єктивною причиною зниження інтересу до друкованої продукції давно визнано Інтернет та Інтернет-технології. Переважна більшість загальнодержавних, певна частина регіональних та місцевих друкованих засобів масової інформації відреагували створенням власних Інтернет-версій. Отже, можна справедливо стверджувати, що швидкість передачі інформації 

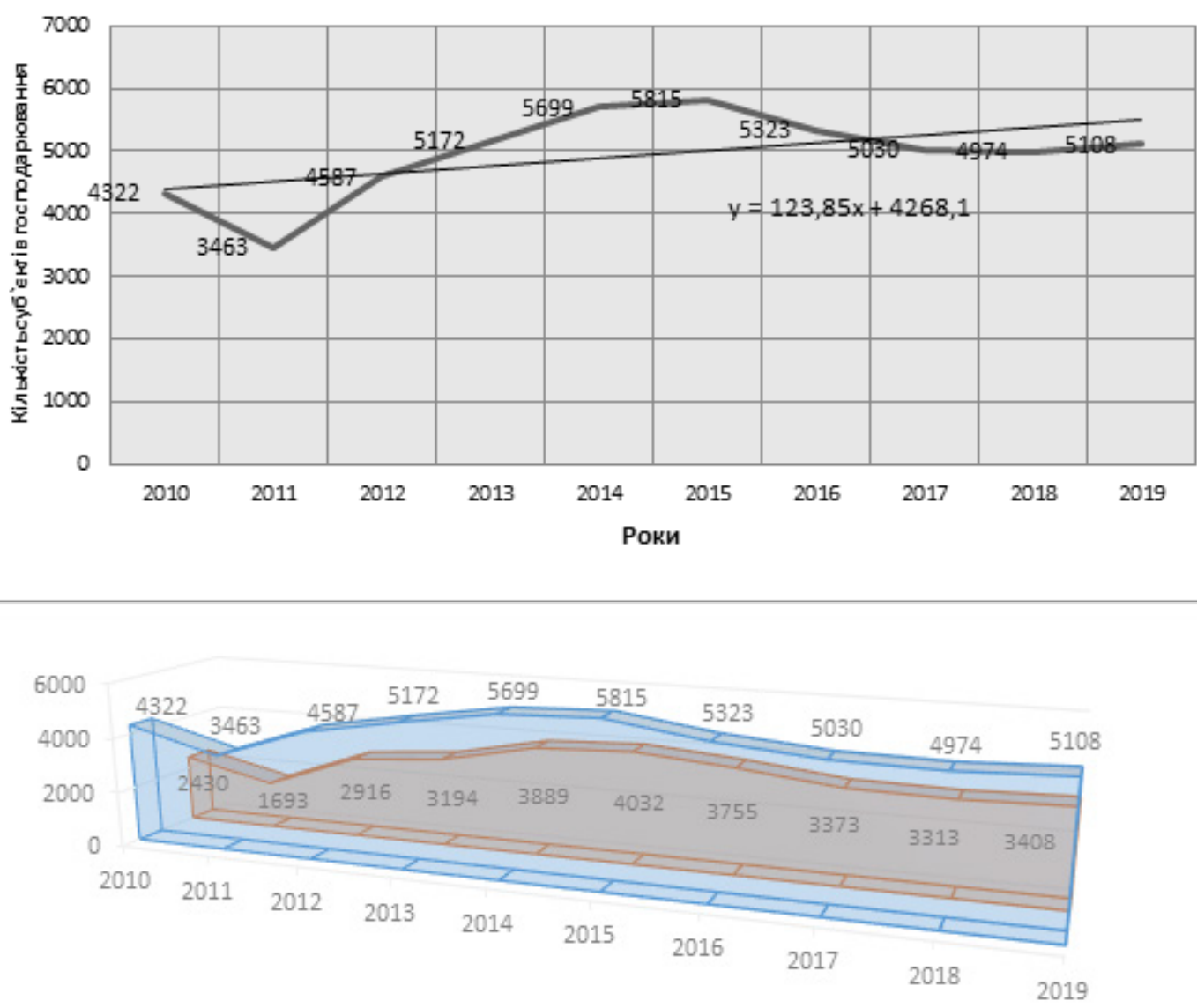

口усього $\quad$ 口з них фізичні особи-підприемці

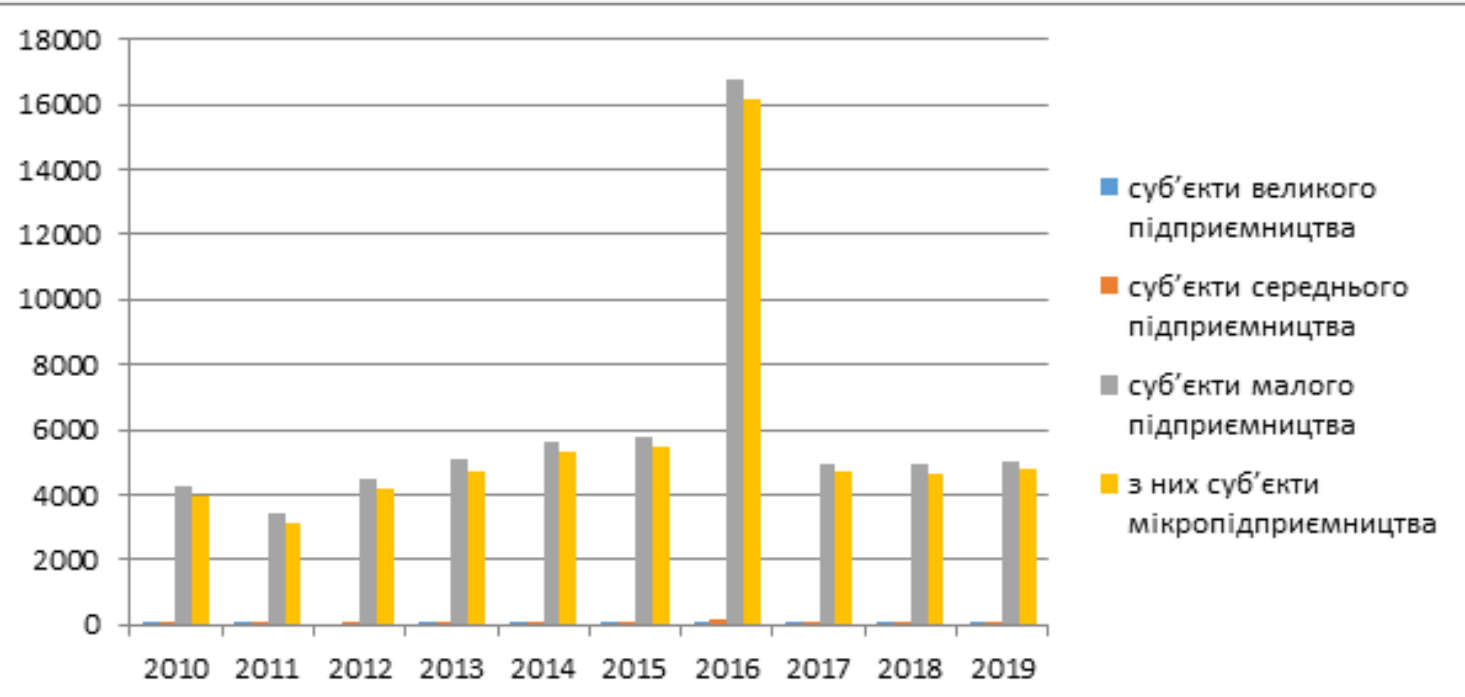

Рис. 1. Кількість суб'єктів господарювання за видом економічної діяльності «поліграфрічна діяльність, тиражування записаної інформації» в Україні 2010-2019 рр

Джерело: складено автором на основі [1]

відіграє важливу роль у видавничій справі, але водночас варто наголосити, що використання невидавничої продукції залишається на високому рівні, оскільки етикетну, пакувальну та іншу комерційну продукцію використовують майже всі підприємства країни.

В заключному звіті Британської Ради (2021 рік) «Видавнича галузь України: огляд сектора» [3] зазначається: 1) видавнича галузь в Україні стикається зі значними труднощами, до яких додаєть- ся нестача надійних статистичних даних і відсутність довіри між представниками галузі; 2) серед прогалин - редагування, розуміння редакційних та видавничих процесів, відсутність знань щодо продажу та просування прав за кордоном і встановлення міжнародних зв'язків; 3) висока якість дизайну, ілюстрації, виробництва і передових технологій друку в Україні засвідчують нові можливості для міжнародної співпраці; 4) в умовах спаду показників книгочитання і попиту на книги (загаль- 
Кількість виготовленої продукції видавничо-поліграфрічної галузі України, 2020 рік

\begin{tabular}{|c|c|}
\hline $\begin{array}{l}\text { Найменування продукції } \\
\text { за Номенклатурою продукції } \\
\text { промисловості (НПП) }\end{array}$ & $\begin{array}{l}\text { Кількість виробленої } \\
\text { промислової продукції } \\
\text { (валове виробництво) }\end{array}$ \\
\hline $\begin{array}{l}\text { Газети, журнали і видання періодичні, які виходять щонайменше чотири рази на } \\
\text { тиждень, віддруковані }\end{array}$ & K / C \\
\hline Каталоги рекламні, віддруковані & $\mathrm{K} / \mathrm{C}$ \\
\hline $\begin{array}{l}\text { Проспекти, плакати та інша рекламна продукція, віддрукована (крім каталогів } \\
\text { рекламних) }\end{array}$ & 10486,2 \\
\hline $\begin{array}{l}\text { Газети, журнали та видання періодичні, які виходять менше чотирьох разів на } \\
\text { тиждень, віддруковані }\end{array}$ & 76043,3 \\
\hline $\begin{array}{l}\text { Книги, брошури, листівки та подібна продукція, у вигляді окремих аркушів, віддру- } \\
\text { ковані }\end{array}$ & 7941,1 \\
\hline $\begin{array}{l}\text { Книги, брошури, листівки та подібна продукція, віддруковані (крім у вигляді окре- } \\
\text { мих аркушів) }\end{array}$ & 25357,0 \\
\hline $\begin{array}{l}\text { Книги-картинки, книги для розмальовування чи розфрарбовування, дитячі, віддру- } \\
\text { ковані }\end{array}$ & 16,9 \\
\hline Поштові листівки, ілюстровані чи ні, віддруковані & $\mathrm{K} / \mathrm{C}$ \\
\hline $\begin{array}{l}\text { Листівки вітальні, інформаційні, з особистими повідомленнями, ілюстровані або } \\
\text { неілюстровані, з конвертами або без конвертів, з прикрасами чи без прикрас, } \\
\text { віддруковані }\end{array}$ & 205,7 \\
\hline Репродукції, гравюри, креслення та фротографії, віддруковані & к / c \\
\hline Календарі усіх видів, уключаючи блокові календарі, віддруковані & 1147,8 \\
\hline Картинки перебивні (декалькоманія), віддруковані & к / с \\
\hline Етикетки та ярлики з паперу чи картону друковані, самосклеювальні & 11967,0 \\
\hline Етикетки та ярлики з паперу чи картону друковані інші (крім самосклеювальних) & 21825,0 \\
\hline Етикетки з паперу чи картону самосклеювальні інші (крім друкованих) & к / C \\
\hline $\begin{array}{l}\text { Етикетки та ярлики з паперу чи картону інші (крім самосклеювальних та друкова- } \\
\text { них) }\end{array}$ & К / C \\
\hline
\end{tabular}

к/с - Дані не оприлюднюються з метою забезпечення виконання вимог Закону України “Про державну статистику” щодо конфріденційності статистичної інформації

Джерело: складено автором на основі [1].

носвітові тенденції), вагомий внесок українських літературних організацій та фрестивалів допоміг підвищити популярність української літератури; 5) більшість видавців під час пандемії повідомили про скорочення накладів, але не кількості опублікованих назв. У представленому звіті також виділені ключові пріоритети подальших досліджень: просування української літератури за кордоном; навчання та навички; розвиток лідерства; розвиток читацької аудиторії.

21 березня 2018 р втратила чинність «Концепції державної політики щодо розвитку національної видавничої справи та популяризації читання на період до 2020 року». Прийняття рішення було зумовлено втратою актуальності даного розпорядження у зв'язку зі створенням Українського інституту книги (офріційний сайт: https://book-institute. org.ua/) та передачею йому відповідних повноважень. Даний інститут покликаний: фрормувати державну політику у книжковій галузі; провадити промоцію книгочитання в Україні; підтримувати книговидавничу справу; стимулювати переклада- цьку діяльність; популяризувати українську літературу за кордоном. Також запрацювала програма поповнення бібліотечних фондів від Українського інституту книги, яка фактично спроможна фрінансувати вихід назви книжок. Отже, проблема видавничої справи в Україні була визнана на національному рівні, хоча вона й стосується в більшій мірі видавців, а не видавничо-поліграфрічної галузі в цілому. Поза увагою все ж залишаються стратегічні проблеми поліграфічної сфрери, хоча вона й складає важливий економічний інтерес для держави.

Ключовими засобами державного впливу на стратегічний розвиток ВПГ, в залежності від умов, в яких вона фрункціонує, можна визнати наступні: програми регіональної та державної підтримки та розвитку ВПГ; закупівля державою видавничої та поліграфрічної продукції; фрінансування науково-дослідних установ; контроль за якістю продукції; програми стимулювання із залучення інвестицій у розвиток галузі; розробка програм екологічної безпеки галузі тощо. 
Наголосимо також на тому, що сьогодні конкуренція в поліграфічній сфері суттєво зросла, i, наприклад, на пошуковий запит «послуги з виготовлення поліграфічної продукції» через пошукову системy Google можна знайти приблизно 856000 результатів пошуку. Глобалізація і відкриття торгових кордонів, коливання попиту та зниження платоспроможності споживачів вимагатиме від виробників видавничо-поліграфрічної продукції підвищення її стратегічної конкурентоспроможності.

Видавничо-поліграфрічна галузь України має власний позитивний досвід розвитку асоційованих форм господарювання. Першою спробою об'єднання зусиль задля вирішення суспільних проблем було створення Української асоціації видавців (УАВ) ще у 1991 році, яка, пізніше, трансформувалась в Українську асоціацію видавців та книгорозповсюджувачів (УАВК). Сьогодні також успішно функціонує Українська асоціація видавців періодичної преси. Мета таких об'єднань — поліпшення фрінансових результатів кожного учасника від спільної діяльності, зниження операційних витрат, загального ризику кожного з членів, фрормування спільної політики розвитку і державної підтримки, захист інтересів членів, сприяння тех- нічному розвитку виробництва тощо.

Варто підкреслити, що на ринку етикеткової, пакувальної, рекламної, бланкової та іншої комерційної продукції домінують приватні та колективні поліграфічні підприємства, які оснащеному сучасною технікою. Такі виробники основними проблемами галузі відзначають погіршення забезпеченості трудовими та матеріальними ресурсами. Однак, необхідною умовою стратегічного розвитку видавничо-поліграфрічної галузі $є$ макроекономічне сприяння та підтримка реалізації галузевих конкурентних переваг [4]. У загальному вигляді формування подальшого стратегічного розвитку ВПГ України можна представити певними етапами (рис. 2).

В умовах реформаційних змін, що проводяться в Україні видавничо-поліграфічна діяльність набуває більшого вираження локальності. За такого підходу постає необхідність розробки багатокомпонентної системи, що дозволить забезпечити не лише ефрективність фрункціонування ВПГ, а й іiї подальший розвиток в умовах ресурсних обмежень. Звідси виникає необхідність розробки просторово-часової фрорми ефрективного ресурсно-

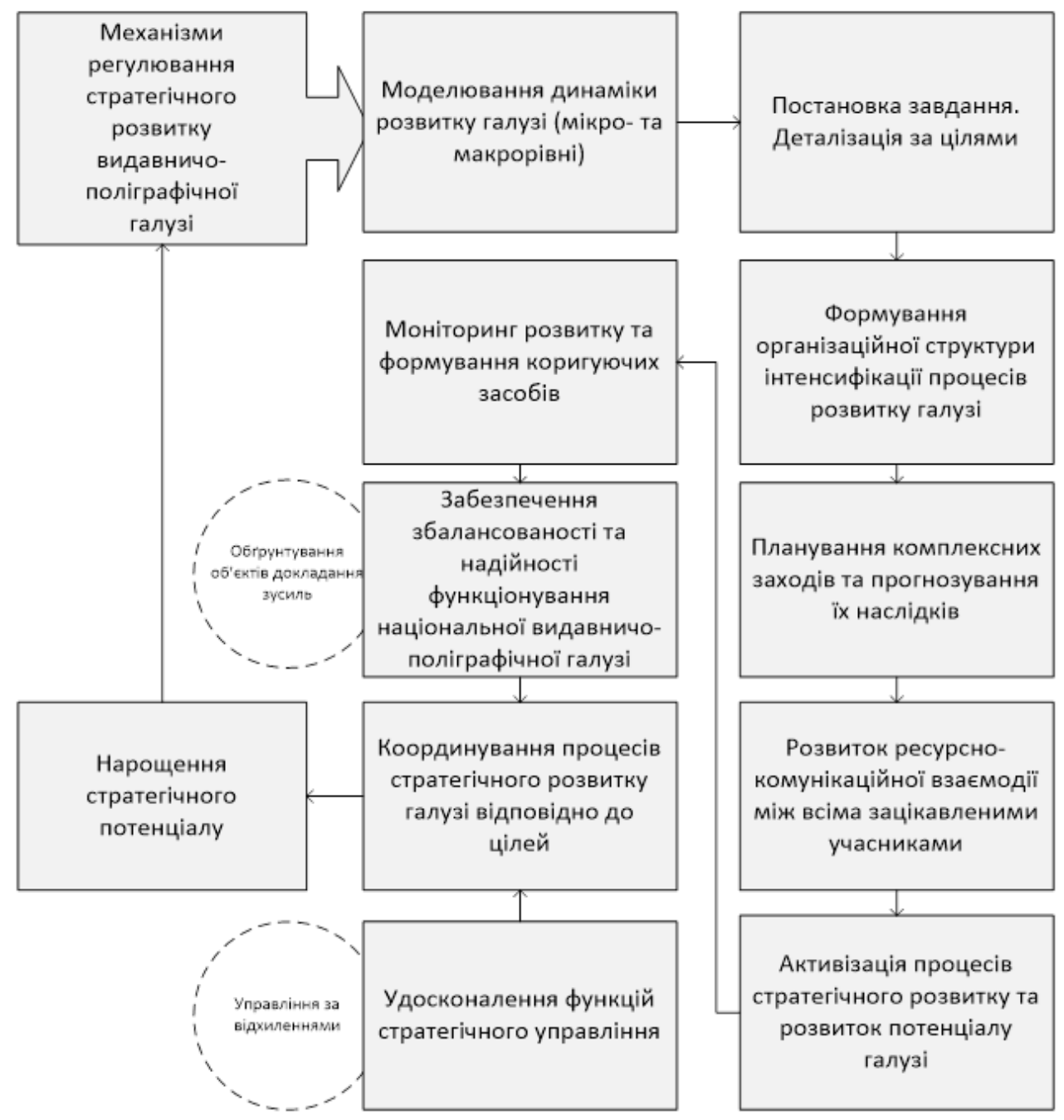

Рис. 2. Схема взаємозв'язків процесу стратегічного розвитку ВПГ 
го забезпечення галузі, що завдяки комунікаційним зв'язкам дозволить оптимізувати процес ресурсного забезпечення та спрямувати ВПГ до розвитку економічного потенціалу галузі.

Підкреслимо, що у сучасних умовах господарювання неможливо приймати об'єктивні стратегічні управлінські рішення через наступні чинники: ринкова ситуація в країні вимагає врахування швидких змін; існує брак часу на підготовку оптимізаційних рішень; відсутня прогнозованість оперативних дій конкурентів; сучасні соціально-економічні процеси вимагають формування адекватного інформаційного простору, недосконалість якого є одним із найвагоміших чинників виникнення ризику.

Висновки. Отже, видавничо-поліграфрічна промисловість $є$ не лише виробничо-технічною базою національного друку, а й стратегічно важливим елементом економіки країни. Значення ВПГ в системі галузей української промисловості характери- зується не обсягом продукції, що виготовляється, а, перш за все, її характером та призначенням. У загальному об'ємі промислової продукції доля поліграфії невелика, вона значно нижча за долю легкої промисловості, машинобудування, харчової промисловості тощо, але вплив як видавництва так і поліграфічної діяльності недооцінений.

На основі проведеного дослідження основними перспективними напрямами подальшого стратегічного розвитку галузі можемо визнати: використання наявного потенціалу галузі та його нарощення; створення єдиної комплексної системи комунікацій в інформаційному просторі; провадження ефективного моніторингу; розширення мережі асоціацій у галузі для забезпечення дієвої взаємодії; вирішення проблемних питань забезпечення ресурсами підприємств видавничо-поліграфрічної сорери для підвищення конкурентоспроможності та нарощення стратегічного потенціалу галузі.

\section{БІБЛІОГРАФІЧНИЙ СПИСОК:}

1. Офріційний вебсайт Державної служби статистики України. URL: http://www.ukrstat.gov.ua/ (дата звернення 20.08.2021).

2. Офіційний вебсайт Державної наукової установи «Книжкова палата України». URL: http://www.ukrbook. net/ (дата звернення 22.08.2021).

3. Звіт Британської Ради «Видавнича галузь України: огляд сектора». 2021. URL: https://www.britishcouncil. org.ua/sites/default/files/333_research_uk_ua_v10.pdf. (дата звернення 21.08.2021).

4. Михайловська О. В., Сахно Є. Ю., Ткаленко Н. В. Ресурсно-інформаційне забезпечення видавничо-поліграфічної галузі України: проблеми та перспективи : монографрія. Київ : Видавничий дім «Кондор», 2016. 164 с.

\section{REFERENCES:}

1. Oficijny j sajt Derzhavnoyi sluzhby` staty`sty 'ky` Ukrayiny` (2021). [State Statistics Servise of Ukraine]. URL: http://www.ukrstat.gov.ua/ [in Ukrainian]. (Accessed 20.08.2021).

2. Derzhavna naukova ustanova «Kny`zhkova palata Ukrayiny` imeni Ivana Fedorova». [Book Chamber of Ukraine]. URL: http://www.ukrbook.net/ [in Ukrainian]. (Accessed 22.08.2021).

3. Zvit Brytanskoi Rady (2021) «Vydavnycha haluz Ukrainy: ohliad sektora» [British Council Report «Ukraine's Publishing: A Sector Overview»] URL: https://www.britishcouncil.org.ua/sites/default/files/333_research_uk_ua_v10. pdf. [in Ukrainian]. (Accessed 21.08.2021).

4. Mykhailovska O. V., Sakhno Ye. Yu. \& Tkalenko N. V. (2016). Resursno-informacijne zabezpechennya vy davny cho-poligrafichnoyi galuzi Ukrayiny”: problemy` ta perspekty 'vy”. [Resource and information support of Ukrainian publishing and printing industry: problems and perspectives] : monograph. Kyiv: Condor Publishing House. 164 p. [in Ukrainian]. 